\title{
THE JOHN HARVARD LIBRART
}

Bernard Bailyn

Editor-in-Chief 



\section{TRAVELS in NEW ENGLAND and $\mathcal{N E W}$ YORK}

\section{$\overline{B Y}$ TIMOTHY DWIGHT}

Edited by Barbara Miller Solomon with the assistance of

Patricia M. King

VOLUME III

The John Harvard Library

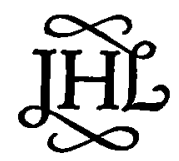

The Belknap Press of

Harvard University Press

Cambridge, Massachusetts

1969 
(C) Copyright 1969 by the President and Fellows of Harvard College All rights reserved

Distributed in Great Britain by Oxford University Press, London

Library of Congress Catalog Card Number: 69-12735

Printed in the United States of America

John Harvard Library books are edited at the Charles Warren Center for Studies in American History, Harvard University. 